\title{
Sustainability practices and lifestyle groups in a rapidly emerging economy: a case study of Chennai, India
}

Terry Tudor*, Chris Holt, Nigel Freestone

School of Science and Technology. University of Northampton. St George's Avenue. Northampton. NN2 6JD. UK

terry.tudor@northampton.ac.uk

chris.holt@northampton.ac.uk

nigel.freestone@northampton.ac.uk

*Corresponding author

G Bhaskaran+, M Suresh ${ }^{+*}$

+Department of Geography. University of Madras. Chepauk. Chennai - 600005 . Tamil Nadu. India

*Centre for Natural Hazards and Management Studies. University of Madras. Chepauk. Chennai -600 005. Tamil Nadu. India

grbhaskaran@gmail.com

sureshgeography@hotmail.com

Sindy Banga

School of Health. University of Northampton. Boughton Green Road. Northampton. NN2 7AL. UK sindy.banga@northampton.ac.uk

\section{Abstract}

The development of strategies to encourage more sustainable approaches to resource consumption is a key global challenge. This is particularly the case within rapidly developing countries such as India, due to rapid urbanisation, population growth and resource consumption. Using households in the Southeastern Indian city of Chennai as the case study, this study sought to examine the extent to which lifestyles could be categorised into groups and the role of the concepts of sustainability on these 
groups. Five lifestyle groups were identified, ranging from 'dedicated environmentalists', to nonenvironmentalist'. Conservation of electricity and water were key sustainability behaviours. Various key factors were found to impact upon the behaviours of individuals in these groups including perceived limitations in time, levels of awareness, as well as values. The implications of the findings for facilitating improved policies and practices are discussed.

\section{Key words:}

Chennai, India, Energy conservation, Water conservation, Recycling, Sustainable development, Proenvironmental behaviours

\section{Biographical notes:}

Dr Terry Tudor is a Senior Lecturer in Wastes Management in the School of Science and Technology at the University of Northampton

Dr Chris Holt is a Senior Lecturer in Environmental Sciences in the School of Science and Technology, at the University of Northampton

Dr Nigel Freestone, is a Principal Lecturer in Wastes Management and Head of Department of Department of Environmental and Geographical Sciences, in the School of Science and Technology, at the University of Northampton

Dr G Bhaskaran is an Assistant Professor in the Department of Geography, at the University of Madras

Professor M Suresh is a Professor and head of the Centre for Natural Hazards and Management Studies, and a Professor in the Department of Geography, at the University of Madras

Dr Sindy Banga is a Senior Lecturer in Psychology in the School of Health, at the University of Northampton 


\section{Introduction}

The concepts of sustainable development have been widely accepted as serving as a model for societal development to mitigate against challenges such as climate change, urbanisation, and resource security (Stern, 2006; ADB, 2011; World Bank, 2011; Le Lay, 2013; Struchtey, 2015; Webster, 2015). Given their rapid development and resource consumption, there is a particular need for more sustainable approaches within the emerging economies of the BRIC (Brazil, Russia, India and China) countries.

India is the second most populous country in the world and with a growth rate of $1.41 \%$, is scheduled to overtake China as number one, within a matter of years (Gol, 2011a). Despite significant socioeconomic progress since independence in 1947, rapid urbanisation, population growth and changing lifestyles have led to rising resource consumption levels in India (GOI, 2011b). This increased consumption has led to calls to address the resource levels, as well as the public health issues associated with consumption, particularly in the rapidly expanding urban areas (Gol, 2011b; Vij, 2012; Joshi, 2013). For example, the urban water supply and sanitation sectors in the country have for some time faced inadequate levels of service, an increasing demand-supply gap, poor sanitary conditions, and deteriorating financial and technical performance (CMWSSB, 2012). It is generally the poor and vulnerable who are most affected by these issues (as they are the users of the marginal resources) (World Bank, 2011).

Using households within the City of Chennai, in the Southeastern Indian State of Tamil Nadu, this study aimed to answer the following three key questions:

1. To what extent did the concepts of sustainability play a role in the consumption trends of households in Chennai?

2. What were the key factors that impacted upon these consumption trends? 
3. Could these factors be constructed into different lifestyle groups and if so, what was the nature of these groups?

Sustainability behaviours in the context of this study, should be taken to mean the conservation of resources (e.g. water and energy, and waste), and mitigation of risks to the environment and human health (e.g. Heath and Binswanger, 1996; Nadal et al., 1998).

\section{Sustainability in Chennai}

The Southeastern state of Tamil Nadu has a population of 72,138,958 (GOI, 2011a). Tamil Nadu constitutes $5.96 \%$ of India's population. The population increased by $15.60 \%$ during the period 2001 2011, compared to $11.70 \%$ during 1991 - 2001.

There are 32 districts in Tamil Nadu, with an average population size of 2,254,342 (GOI, 2011a). Chennai is the most populous district in Tamil Nadu, with 4, 681,087 individuals. According to the UN (2011), Chennai is ranked $4^{\text {th }}$ among India's urban areas and the population will approach 10 million by 2025 . In addition, it is one of the most dense districts in India at 26,903 individuals per sq km, compared to the national average of 382 persons per sq $\mathrm{km}$.

Chennai faces significant environmental and public health challenges (WHO, 2011; World Bank, 2011), related to energy and water consumption and the sustainable management of its waste. One of the major causes of environmental concern across Chennai and India generally, is air pollution, resulting in deleterious impacts on the health and wellbeing of the population (World Bank, 2011). Key causes of the rise in air pollution have been increased industry, vehicles and indoor pollution in the poorer areas, with energy and power related sources accounting for $75 \%$ of the $\mathrm{CO}_{2}$ emissions (WHO, 2011). According to ADB (2011), Chennai and Delhi are the two worst performing cities in India in terms of water availability per day. With a steadily increasing population, the city has faced water shortages, and its ground water levels have been depleted. Despite the introduction of various water conservation strategies, Chennai is expected to face a significant deficit of daily demand versus supply 
of water within the next 10 years (CMWSSB, 2012). Around 3,200 million tonnes of waste, equating to a percapita rate of $500 \mathrm{~g}$, are collected each day in the city, with the majority $(68 \%)$, coming from households (CoC, 2012). Thus, given its size, growing population and changing lifestyles, Chennai served as a good case study region for this research.

\section{Facilitating sustainable lifestyles}

Various determinants for sustainable lifestyles have been identified by a number of studies. These influencing factors operate in a dynamic and interrelated manner (Burger, 2006; Kollmuss and Agyeman, 2002; Christen and Schmidt, 2011). At the individual level, amongst the most common factors have been: Cognitive and affective constructs (e.g. perceptions, environmental attitudes, habits, values and beliefs) (Barr et al., 2003; Bamberg \& Möser, 2007; Kaiser, Schultz, Scheuthle, 2007; Hirsh, 2010; Tudor et al., 2008; Upham et al., 2009); Situational factors (Barr, 2002; Robinson and Read, 2005) and Socio-economic constructs (GFS, 2011); Socio-psychological factors such as altruism (Schwartz, 1992), biocentric and anthropocentric constructs (Dunlap et al., 2000); and Ecocentrictechnocentric factors (O'Riordan, 1985). At a wider level, more holistic factors have been shown to be significant. For example, local governance strategies involving a participatory approach have become a key focus for development intervention to achieve environmentalism (Tudor, 2009; Williams, 2009).

UNDP (2008) found that strategies to manage local resources needed first to mobilise local communities and create institutions in order to ensure equity and empowerment. For example, informal sector recycling of waste using a participatory approach, has been shown to improve sustainability, leading to an enhanced sense of place, reduced levels of poverty and contributing to the local economy (Colon and Fawcett, 2006; Wilson et al., 2006). Various studies have suggested that facilitating more sustainable lifestyles requires a 'deliberative model' of public engagement, with social and environmental issues framed within a spatial and temporal context to facilitate action 
(Blake, 1999; Owens, 2000). Indeed, providing feedback on progress at the community level, as well as encouraging social networking have also been shown to positively impact upon community participation and engagement with the sustainability agenda (Vance-Borland and Holley, 2011; Le Lay et al., 2013). Christen and Schmidt (2012) also argue that social justice provides a framework not only for what initiatives are embedded, but also how they can be sustained.

A number of studies primarily from the fields of social-psychology and human geography have posited that environmental actions can be defined in terms of the social composition of different groups (e.g. demographic profile, situational factors such as provision of recycling, and structural factors such as knowledge of environmental issues) (Schultz et al., 1995; Barr and Gilg, 2006).

However, a limitation of most of the studies mentioned above is that they have primarily been conducted within a Western context. A case study of a rapidly developing Southeast Asian country, particularly one from the BRICs, therefore provides the opportunity for a wider and balanced perspective. Specifically related to India, there have been limited recent large scale empirical studies focusing on sustainable lifestyles.

\section{Methods}

\subsection{Sampling approach}

The survey was undertaken between February and April, 2011. The map of the Chennai was first spatially stratified into four regions and households were then visited at around every $15^{\text {th }}$ house, within each of these four quadrants. However, as the focus was on households and given the higher levels of industry and commerce in the North, West and Southwest, sampling was biased towards the regions outside of these three areas, where there were more houses located.

\subsection{Questionnaire design}


The questionnaire was designed using Dillman's (1978) Total Design Method. It sought to examine a range of factors related to the environmental practices of individuals in Chennai and the key antecedents for these behaviours, including cognitive and affective, situational and sociopsychological factors.

Data were collected on the socio-demographic characteristics of the individuals, their values, beliefs, perceptions towards the environment, levels of awareness and sources of information and sustainability practices. Based on previous household focused studies (e.g. Barr et al., 2003; Colon and Fawcett, 2006; World Bank, 2011), these practices were determined at the outset to include issues such as waste minimisation and recycling, and conservation of water and electricity. Thus examples of questions included: 'Modifying the environment for human use seldom causes serious problems', 'My lifestyle affects the environment in Chennai', 'I try to save water in the bathroom and kitchen', 'I switch off lights in unoccupied rooms', 'What each person does has an impact on the society and the environment', 'The more others help the environment, the more I will', 'I would recycle if there were bins', I would recycle if I knew where to recycle'. In addition, the study sought not only to identify the antecedents and practices, but also to gauge which of the issues were considered to be most significant, by determining the frequency of mention.

The responses were measured using a series of Likert-style agreement scales (e.g. strongly agree to strongly disagree). Some 1,000 questionnaires were distributed to the households. The questionnaires were distributed using a 'drop and collect' method, in order to ensure as high a return rate as possible and also to enable the researchers to answer any queries which the householders had. A total of 712 questionnaires were returned, representing a response rate of $71 \%$.

\subsection{Statistical analyses}


The analyses sought to identify the socio-demographic characteristics of the sample, the key sustainability practices and the antecedents for these behaviours. In order to determine these factors, the data were first tested for normality using both the Kolomogorov-Smirnoff Test and Shapiro-Wilk Test. As the Sig. levels were $<0.005$, the data were assumed to be non-normal. Therefore nonparametric bivariate tests including $\chi^{2}$ and Spearman Rank coefficients were determined. As the data were primarily non-parametric, the use of bivariate statistics, such as Spearman's Rank Correlation Coefficient ( $\mathrm{rs}$ ) provided a measure of statistical significance of the results. As a means of developing the lifestyle groups, factor analyses, as well as cluster analyses were undertaken. Cluster analysis examines the scores provided on a series of questionnaire items. The choice of the number of clusters is subjective, but is based on 'cutting' the graph in a dendrogram to result in a series of groups. The cumulative $\%$ of Variance for the factor analyses was 45.731 , which suggests that the results can be confidently reported. SPSS ver 17 was used for all of the analyses.

\section{Results}

\subsection{The respondents}

The respondents were typically male $(64.6 \%)$, in the age range of $18-25$ years old $(38.5 \%)$, not employed/not in the labour force (29.1\%) and living in a house with four persons (36.8\%) (Table 1). As the sample compares favourably with the 2011 Indian Census, the results can be confidently reported.

\section{PLACE TABLE 1 HERE}

\subsection{Key sustainability actions employed}

The key environmental concerns expressed were about the need to conserve water (4.12), global warming (4.01), conservation of electricity (3.89) and recycling of waste (3.74). Thus there were three main sustainability practices that were reported practiced by the households, namely switching off of the lights $\left(\chi^{2}=965.81\right)$, conserving water $\left(\chi^{2}=875.16, d f=5, p<0.001\right)$, and recycling of recyclables such 
as plastics, paper and bottles $\left(\chi^{2}=478.66, d f=5, p<0.001\right)$. In addition to these, the other key actions employed were reuse of materials (e.g. reusing glass bottles and plastic bags from shopping, for other purposes) $\left(\chi^{2}=500, d f=5, p<0.001\right)$.

\subsection{Drivers for the sustainability practices}

The sustainability practices were influenced largely by cognitive and affective constructs (primarily attitudes and beliefs), levels of awareness, as well as socio-psychological factors such as social justice and equality (Table 2).

\section{PLACE TABLE 2 HERE}

The overarching influencing factor was the view that they did not have enough time to behave in a sustainable manner. In addition to the influence of environmental beliefs and attitudes, awareness also played a key role. This was especially true for recycling. For example, respondents mentioned the need for more in-depth information on how they could be more sustainable and specifically information on what happened to their recyclables. They also wanted to have the correct bins in order to be able to recycle. Recycling and reuse of bottles and scrap paper were the most commonly mentioned sustainable waste management approaches employed.

Overall, there were strong links between the various sustainability behaviours. For example, conservation of water was strongly linked to saving energy $\left(0.510^{* *}\right)$ and recycling $\left(0.361^{* *}\right)$.

Socio-demographic factors generally did not have a significant impact upon behaviour.

\subsection{Examining the lifestyle groups}

In order to identify and examine the lifestyle groups, a factor analysis, followed by a cluster analysis was undertaken. Mean scores run from 1 (lowest), to 5 (highest). Table 3 indicates that there were seven main factors, linked to logistics, awareness and beliefs that impacted upon the overall 
sustainability practices (i.e. conservation of water and electricity, and recycling), of residents in Chennai, namely:

- Factor 1: Lack of time

- Factor 2: The belief that most others did little for the environment

- Factor 3: The need for more information about recycling

- Factor 4: Having the correct bins in order to recycle

- Factor 5: The degree to which the individual considered themselves to be environmentally friendly

- Factor 6: Beliefs about the potential threat of environmental pollution

- Factor 7: Beliefs about the potential impacts of global warming as a result of saving energy

\section{PLACE TABLE 3 HERE}

In addition to the factors, five main clusters were identified and can be classified as follows:

- Non-environmentalist (no. 255)

- Occasional environmentalist (no. 123)

- Main stream environmentalist (no. 62)

- Committed environmentalist (no. 190)

- Dedicated environmentalist (no. 81)

In order to examine differences in behaviours between groups, the means of selected behavioural clusters and the Kruskal Wallis statistics were investigated. Table 4 demonstrates that environmental attitudes, awareness and social values were the key influencing and differentiating factors between the five lifestyle clusters of practices.

PLACE TABLE 4 HERE 
The highly significant difference in scores in Table 4 for perceptions of limitation in time indicates that it was the key factor differentiating practice amongst the five clusters. Lack of time was the main reason given by the non-environmentalist. However, the dedicated environmentalist made the time. Another significant issue was whether individuals believed that others in their community were engaged in sustainability practices. For example, the non-environmentalist reported that as their neighbours did little for the environment, why should they? An interesting influencing factor was knowledge of where to recycle, with all except the main-stream environmentalist reporting this as being a barrier to sustainable practice. Indeed, limitation in awareness about how to act sustainably, was a significant issue for each of the clusters. Finally, a range of socio-psychological values such as altruism, biocentric and anthropocentric constructs and ecocentric-technocentric factors were also found to influence the practices of householders. However, there was limited variation across the clusters, with environmental values playing a generally strong role in the practices of individuals from all five clusters. The notable issue with regard to values was the seeming discrepancy between the fact that there should be social justice, juxtaposed with views of 'humans ruling the world' and there being no 'limits to growth' for India. With respect to 'enjoying the luxuries of life', there was a slight difference between the dedicated environmentalists and individuals from the other four clusters.

\section{Discussion}

This study has examined the issue of sustainable practices and lifestyle groups in Chennai. There were three key issues that emerged from the data.

First, five main clusters of behaviours were identified, ranging from the 'non-environmentalist' (who espoused a sense of pro-environmental behaviours), to the 'dedicated environmentalist' who shared largely opposite views. Whilst the dedicated and committed environmentalists engaged strongly in sustainable practices, the 'non-environmentalist' and 'occasional environmentalist' (which combined represented $53 \%$ of the sample) rejected most environmental practices. The key differentiating factors between the clusters were perceived limitations in time and awareness. Socio-psychological values 
were generally consistently high across all five clusters. The strong influence of values confirms the importance of cognitive and affective constructs on sustainability practices (Barr et al., 2003; Bamberg \& Möser, 2007; Kaiser, Schultz, Scheuthle, 2007; Hirsh, 2010; Tudor et al., 2008; Upham et al., 2009). Second, there were three key factors that limited the 'non-environmentalist' and 'occasional environmentalist' from behaving in a more sustainable manner, namely: (1) a perceived lack of time; (2) limitations in awareness about what was required (e.g. what could be recycled or where); and (3) the perception that others did little for the environment and hence why should I? (Table 4). Unlike for the conservation behaviours, but similar to previous studies, barriers to recycling were less psychological and more logistical (e.g. having the correct bins and awareness levels), (Barr, 2002; Robinson and Read, 2005, Harza and Goel, 2009). This may relate to the fact that recycling is a more normative behaviour, and is therefore less dependent on psychological triggers (Barr et al., 2003; Tudor et al., 2008; Upham et al., 2009). The influence of what others did on individual behaviour is similar to Vij (2012), who found that public apathy, particularly within communities played a significant role in how engaged households and individuals were with more sustainable practices.

Third, the main reported sustainability practices employed by the households were conservation of electricity and water and to a lesser extent, recycling of items. However, a crucial point here is that similarly to Barr and Gilg (2006), the environmental practices transcended the narrow boundaries of the individual practices of water conservation, waste management and energy conservation. Indeed, the behaviours were influenced largely by the beliefs and perceptions of the households towards the environment. Conservation of electricity and water were most likely highlighted because both are essential resources that are in increasingly limited supply in Chennai. Water is an essential every day necessity for all, however, Chennai has for many decades experienced water shortages linked to factors such as aged pipes and supply systems, and unpredictable weather patterns (Gol, 2011b; CMWSSB, 2012). With continual expansion in the physical infrastructure, as well as in industry and commerce within the city and its environs, the quantities of electricity consumed have risen significantly and will by all accounts continue to do so. In addition, limitations in water and electricity 
are likely to have a more significant and immediate impact on the day to day lives of individuals, as compared to recycling, and thus would be more likely to be mentioned. Concerns were also raised by the non-environmentalist about what others were doing. With a rapidly increasing population and urbanisation, it is inevitable that there would be some loss of the 'community spirit', and therefore perceptions about what others are or are not doing.

\subsection{Implications for policy and practice}

The current rates of resource consumption in Chennai are unsustainable. Unchecked, they will continue to further impact negatively upon the health and livelihoods of residents, as well as on their access to a decent life (Gol, 2011b). Increased consumption will place even more pressure on already limited availability and supply of water and electricity. It is the most vulnerable and those living on the fringes of the urban environments who will be most impacted upon by increased greenhouse gas emissions, as well as ready access to and availability of potable water and energy supplies.

Despite the number of Government policies and initiatives that have been put in place at the national level, as well as in Chennai (e.g. construction of desalination plants along the coast), there is evidently more that needs to be done.

First, a crucial issue is that Government initiatives should emphasise to households that acting in a sustainable manner does not have to be time consuming. Indeed, actions such as conserving energy and water should be routine and habitual.

Second, awareness raising is crucial. It is important though that it should be targeted. The results from this study suggest that individuals across Chennai do not share the same environmental attitudes, values and levels of awareness and neither do they have similar environmental behaviours. Government should seek to target its sustainability messages and initiatives towards selected segments of the population. The strong links between the sustainability behaviours suggests that for example, conservation of water should also lead to improvements in energy conserved and the levels 
of recycling practiced. Thus, there should be a holistic approach adopted in terms of the messages employed and the coordination of the efforts of the Government agencies involved (e.g. the Pollution Control Board and the Bureau of Energy Efficiency).There should also be public dialogue as to the infiniteness of resources and the costs and tradeoffs that are expected from rising consumption. It would be impossible for Government to meet all of the expectations of households and industry. There have to be limits set as a means of regulating use. If these limits are exceeded, then there has to be an awareness of what can and cannot be provided.

Fourth, the strong links between the more sustainable management of resource consumption, and the impacts upon the health and wellbeing of individuals should be emphasised. Indeed, altruism played a key role in the beliefs of the respondents. Therefore key triggers to be employed to change the environmental behaviour of households should include social justice, equality and ensuring the health and wellbeing of the population.

Fifth, while actions should be encouraged at the individual level, community-wide initiatives also need to be facilitated to encourage a greater sense of community. Partnerships should be built between Government agencies and local organisations as a means of disseminating information and building awareness at the community level. Similarly to previous studies (e.g. Markandya, 2001; Daniere et al., 2002; UNDP, 2007; Williams, 2009; Vance-Borland and Holley, 2011; Le Lay et al., 2013), mobilisation of local communities and creating institutions using a participatory approach, in order to ensure equity and empowerment should be important considerations.

Sixth, individuals and communities also have to take responsibility for their own actions and their expectations have to be managed. The local Government in the State of Tamil Nadu therefore needs to facilitate greater engagement with households when developing their policies and strategies. The results suggest the importance of engagement with householders to encourage them to conserve the resources being used. There should be incentives (e.g. the use of economic instruments such as rebates, product charges for households, and tradable permits for businesses), put in place to 
encourage more sustainable practice. In addition, there could perhaps be encouragement for practices such as using treated water for purposes other than drinking and cooking, encouragement for the use of renewables as has been employed in other states such as Gujarat and Kerala, and reduced costs for energy saving devices. Linked to these 'carrots' should also be 'sticks', in the form of penalties for exceeding usage could be utilised. In addition, to ensure that impacts on the environment are fully accounted for and market failures are limited, further policies and regulations, as well as the pricing of utilities/commodities should incorporate potential damage to the environment (perhaps using direct charging). In this way, growth and development would be managed in a more sustainable manner and there would be monies to pay for the necessary resources and infrastructure (e.g. regulatory and enforcement agencies).

\section{Conclusions}

Chennai is at a critical point, with increasing resource consumption, a rising population, increasing shortages of key resources such as electricity and water, and predictions that these issues will become even more acute in future. Coupled with these, the findings from this study suggest that sustainability played a limited role in the lifestyle of the majority of the households. There is an urgent need for a more sustainable approach if resources are not to become even more stretched. It is important therefore that urgent strategies be employed. These measures should be holistic rather than piecemeal, targeted towards selected lifestyle groups, facilitate wide spread community participation, and seek to build capacity and awareness amongst households. It is only in this way that resilience can best be built into the policies and practices of one of India's largest and fastest growing cities. 


\section{References}

ADB (Asian Development Bank) (2011) Water sector operations in India: review and way forward. Manila: Philippines.

Bamberg, S. and Möser, G. (2007) 'Twenty years after Hines, Hungerford and Tomera: a new metaanalysis of psycho-social determinants of pro-environmental behaviour', Journal of Environmental Psychology, Vol. 27, pp. 14 - 25

Barr, S., and Gilg, A. (2006) 'Sustainable lifestyles: framing environmental action in and around the home', Geoforum, Vol. 37, pp.906-920.

Barr, SW. (2002) Household waste in social perspective: values, attitudes, situation and behaviour. Ashgate Publishing Ltd.

Barr, SW., Gilg, AW. and Ford, NJ. (2003) 'Attitudes towards recycling household waste in Exeter, Devon: quantitative and qualitative approaches', Local Environment, Vol. 8, No. 4, pp. 407-421.

Blake, J. (1999) 'Overcoming the 'value-action' gap in environmental policy', Local Environment, Vol. 4, pp. $257-278$.

Burger, P. (2006) 'Why any substantial definition of sustainability must fail - and why this is a good, not a bad story'. International Sustainable Development Research Conference 2006. Conference Proceedings. University of Hong Kong: Hong Kong.

Burton, RJF. and Wilson, G. (2006) 'Injecting social psychology theory into conceptualisation of agricultural agency: towards a post-productivist self-identity', Journal of Rural Studies, Vol. 22, pp. 95 $-115$. 
Christen, M. and Schmidt, S. (2012) 'A formal framework for conceptions of sustainability - a theoretical contribution to the discourse in sustainable development', Sustainable Development, Vol. 20, pp. $400-410$. DOI: $10.1002 /$ sd. 518

CMWSSB (Chennai Metropolitan Water Supply and Sewage Board) (2012) Chennai metro water. Available at: http://www.chennaimetrowater.tn.nic.in/ Accessed on 14/8/2012

CoC (Corporation of Chennai) (2012) Solid waste management. http://www.chennaicorporation.gov.in/departments/solid-waste-management/index.htm Accessed on $9 / 7 / 2012$.

Colon, M. and Fawcett, B. (2006) 'Community-based household waste management: lessons learnt from EXNORA's zero waste management scheme in two south Indian cities', Habitat International, Vol. 30, pp. 916-931

Dillman, RA. (1978) Mail and telephone surveys: the Total Design Method. Wiley, Chichester.

Dunlap, RE., Van Liere, KD., Mertig AG. and Jones, RE. (2000) 'Measuring endorsement of the new ecological paradigm: a revised NEP scale', Journal of Social Issues, Vol. 56, pp. $425-442$.

GFS (Global Food Security) (2011) Global food security: strategic plan 2011 - 2016. Available at http://www.foodsecurity.ac.uk/assets/pdfs/gfs-strategic-plan.pdf

Gol (Government of India) (2011a) Census. Ministry of Home Affairs. Delhi. India. Available at http://censusindia.gov.in/2011-prov-results/prov data products tamilnadu.html Accessed on $\underline{9 / 7 / 2012}$

Gol (Government of India) (2011b) Sustainable development: stocktaking in the run up to Rio+20. Ministry of Environment and Forests. Delhi. India. 
Harza, T. and Goel, S. (2009) 'Solid waste management in Kolkata, India: practices and challenges', Waste Management, Vol. 29, No. 1, pp. $470-478$

Heath, J. and Binswanger, H. (1996) 'Natural resource degradation effects of poverty and population growth are largely policy-induced: the case of Colombia', Environment and Development Economics, Vol. 1, No. 10, pp. 65-84.

Hirsh, JB. (2010) 'Personality and environmental concern', Journal of Environmental Psychology, Vol. 30, pp. $245-248$.

Joshi, R. (2013) 'Does escalating conflict and conservation challenges allow the Asian elephants to coexist with humans in North India?', International Journal of Environment and Sustainable Development, Vol. 12, No. 3, pp. 205 - 221

Kaiser, FS., Schultz, PW. and Scheuthle, H. (2007) ,The theory of planned behaviour without compatibility? Beyond method bias and past trivial associations', Journal of Applied Social Psychology, Vol. 37, pp. $1522-1544$.

Kollmuss, A. and Agyeman, J. (2002) 'Mind the gap: why do people act environmentally and what are the barriers to pro-environmental behaviour?', Environmental Education Research, Vol. 8, No. 3, pp. $239-260$.

Le Lay, Y-F., Piégay, H. and Rivière A. (2013) 'Perception of braided river landscapes: implications for public participation and sustainable development', Journal of Environmental Management, Vol. 119, pp. $1-12$

Nadal, A. et al. (1998) Maize in Mexico: some environmental implications of the North American Free Trade Agreement (NAFTA). Commission for Environmental Cooperation. Montreal. Canada.

O'Riordan, T. (1985) 'Future directions in environmental policy', Environment and Planning A, Vol. 17, pp. $1431-1446$. 
Owens, S. (2000) 'Engaging the public: information and deliberation in environmental policy. Environment and Planning A', Vol. 32, pp. $1141-1148$.

Robinson, GM. and Read, AD. (2003) 'Recycling behaviour in a London borough: results from largescale household surveys', Resources Conservation and Recycling, Vol. 45, No. 1, pp. 70-83.

Schultz, PW., Oskamp, S. and Mainieri, T. (1995) 'Who recycles and when? a review of personal and situational factors', Journal of Environmental Psychology, Vol. 15, pp. $105-121$.

Schwartz, S H. (1992) 'Universals in the content and structure of values: Theory and empirical tests in 20 countries', in Zanna M. (Ed.), Advances in Experimental Social Psychology, Vol. 25, pp. 1-65. New York: Academic Press.

Stern, PC., Dietz, T. and Guagnano, GA. (1995) 'The new ecological paradigm in social-psychological context. Environment and Behavior', Vol. 27, pp. $723-743$.

Struchtey, M. (2015) Rethinking the water cycle: how moving to a circular economy can preserve our most vital resource, McKinsey and Company. Available at: http://www.mckinsey.com/insights/sustainability/rethinking the water cycle?cid=other-eml-nsl$\underline{\text { mip-mck-oth-1506 }}$

Stern, N. (2006) The Stern review on the economics of climate change. HM Treasury. London. UK Tudor, TL., Barr, SW. and Gilg, AW. (2008) 'A novel conceptual framework for examining environmental behaviour in large organisations: a case study of the Cornwall National Health Service (NHS) in the UK. Environment and Behavior', Vol. May 40, No. 3, pp. 426-450.

Tudor, TL. (2009) 'Sustainable waste management and climatic change', in Kudrow NJ. (ed.). Conservation of Natural Resources. Environmental Science, Engineering and Technology. $237-247$. Nova Publishers. USA. 
UN (United Nations) (2011) World population prospects. Department of Economic and Social Affairs Population Division. NY. USA.

Upham, P., Dendler, L. and Bleda, M. (2009) 'Carbon labelling of grocery products: Public perceptions and potential emissions reductions', Journal of Cleaner Production, Vol. 19, No. 4, pp. 348-355.

Vance-Borland, K. and Holley, J. (2011) 'Conservation stakeholder network mapping, analysis and weaving', Conservation Letters, Vol. 4, No. 4, pp. 278 - 288

Vij, D. (2012) 'Urbanisation and solid waste management in India: present practices and future challenges', Procedia-Social and Behavioral Sciences, Vol. 37, pp. $437-447$.

Webster, K. (2015) The circular economy: a wealth of flows. Ellen MacArthur Foundation.

Williams, G. (2009) 'Good governance', in Kitchin R., Thrift N. (eds.) International encyclopaedia of human geography. London: Elsevier. 606-614

Wilson, DC., Velis, C. and Cheeseman, C. (2006) 'Role of informal sector recycling in waste management in developing countries', Habitat International, Vol. 30, pp. $797-808$.

World Bank (2011) World development indicators. Washington, DC. USA

World Health Organization (2011) Indoor air pollution and household energy. http://www.who.int/heli/risks/indoorair/indoorair/en/index.html Accessed on 1/3/2012 
Table 1: Socio-demographic profile of the individuals sampled

\begin{tabular}{|c|c|c|c|c|}
\hline Factor & & Frequency & Percentage & $\begin{array}{l}\text { Tamil Nadu } \\
(\%) *\end{array}$ \\
\hline Gender & $\begin{array}{l}\text { Male } \\
\text { Female }\end{array}$ & $\begin{array}{l}459 \\
252\end{array}$ & $\begin{array}{l}64.6 \\
35.4\end{array}$ & $\begin{array}{l}51.4 \\
48.6\end{array}$ \\
\hline Age range & $\begin{array}{l}0-17 \\
18-25 \\
26-35 \\
36-45 \\
46-55 \\
55+\end{array}$ & $\begin{array}{l}184 \\
273 \\
145 \\
9 \\
64 \\
35\end{array}$ & $\begin{array}{l}25.9 \\
38.5 \\
20.4 \\
1.3 \\
9.0 \\
4.9\end{array}$ & $\begin{array}{l}35.3^{* *} \\
18.4^{* * *} \\
27.6^{* * * *} \\
18.3^{* * * * *}\end{array}$ \\
\hline Job category & $\begin{array}{l}\text { Not employed/in the labour force } \\
\text { Unskilled manual } \\
\text { Skilled manual } \\
\text { Admin/clerical } \\
\text { Professional } \\
\text { Manager/senior official } \\
\text { Retired }\end{array}$ & $\begin{array}{l}207 \\
63 \\
128 \\
42 \\
186 \\
38 \\
23\end{array}$ & $\begin{array}{l}29.1 \\
8.9 \\
18.0 \\
5.9 \\
26.2 \\
5.3 \\
3.2\end{array}$ & $\begin{array}{l}37 \\
63^{* * * * * *}\end{array}$ \\
\hline $\begin{array}{l}\text { Number of person } \\
\text { living in the house }\end{array}$ & $\begin{array}{l}1 \text { person } \\
2 \text { persons } \\
3 \text { persons } \\
4 \text { persons } \\
5 \text { persons } \\
6 \text { or more persons }\end{array}$ & $\begin{array}{l}37 \\
38 \\
133 \\
262 \\
163 \\
82\end{array}$ & $\begin{array}{l}3.8 \\
5.3 \\
18.7 \\
36.8 \\
27.9 \\
11.5\end{array}$ & \\
\hline
\end{tabular}

*Source: Gol (2011a)

${ }^{* *}$ Age $0-14$

***Age $15-24$

$* * * *$ Age $25-44$

$* * * * *$ Age $45+$

$* * * * * *$ Most of the employed worked in agriculture, forestry and fishing $(52.9 \%)$, or the tertiary/services sector (27.8\%) 
Table 2: Bivariate correlations for factors impacting upon sustainability behaviours

\begin{tabular}{|l|l|l|}
\hline Category & Factor & Correlation coefficient \\
\hline Attitude & I don't have the time & $0.392^{* *}$ \\
\hline Awareness & $\begin{array}{l}\text { I would recycle if I knew where to and what } \\
\text { happens to the recyclables }\end{array}$ & $0.392^{* *}$ \\
\hline Attitude & $\begin{array}{l}\text { Exploitation of natural resources should be } \\
\text { stopped }\end{array}$ & $0.313^{* *}$ \\
\hline Attitude & $\begin{array}{l}\text { I would save energy if I had energy saving } \\
\text { bulbs }\end{array}$ & $0.312^{* *}$ \\
\hline Logistics & Having the correct bins & $0.306^{* *}$ \\
\hline Belief & Social justice & $0.295^{* *}$ \\
\hline Belief & Equality for all & $0.287^{* *}$ \\
\hline Belief & Ensuring the wellbeing of others & $0.279^{* *}$ \\
\hline Awareness & I need more information & $0.274^{* *}$ \\
\hline Belief & Protects the environment & $0.270^{* *}$ \\
\hline Belief & Ensuring the wellbeing of others & $0.264^{* *}$ \\
\hline Belief & Reducing waste saves landfill space & $0.254^{* *}$ \\
\hline
\end{tabular}

** $p<0.001$ 
Table 3: Key overarching factors that impacted upon pro-environmental behaviours

\begin{tabular}{|l|l|l|l|}
\hline & Factor 1 & Factor 2 & Factor 3 \\
\hline I don't have the time & 0.307 & $\mathbf{0 . 7 0 9}$ & 0.090 \\
\hline Most don't do anything for the environment & 0.328 & $\mathbf{0 . 6 8 0}$ & 0.127 \\
\hline I would recycle if I knew where to & $\mathbf{0 . 6 5 6}$ & -0.190 & -0.395 \\
\hline I need more information about recycling & $\mathbf{0 . 6 1 0}$ & -0.330 & -0.115 \\
\hline I would recycle if I had the correct bins & $\mathbf{0 . 5 8 7}$ & -0.178 & -0.516 \\
\hline I consider myself to be environmentally friendly & $\mathbf{0 . 5 4 5}$ & -0.214 & $\mathbf{0 . 4 3 8}$ \\
\hline Environmental pollution is a threat to me & $\mathbf{0 . 5 2 3}$ & -0.229 & 0.270 \\
\hline Saving energy reduces global warming & $\mathbf{0 . 4 9 0}$ & -0.289 & 0.394 \\
\hline \% Var & $\mathbf{2 2 . 6 2 8}$ & 14.706 & 8.397 \\
\hline
\end{tabular}


Table 4: Socio-psychological differences between the five clusters

\begin{tabular}{|c|c|c|c|c|c|c|c|}
\hline \multirow[t]{2}{*}{ Factor } & \multicolumn{6}{|c|}{ Means } & \multirow{2}{*}{$\begin{array}{c}\text { Kruskal } \\
\text { Wallis } \\
(p=0.00)\end{array}$} \\
\hline & NonE & OccE & MainE & CommittedE & DedicatedE & $\%$ Var & \\
\hline \multicolumn{8}{|l|}{ Attitudes/beliefs } \\
\hline No time & 4 & 3.28 & 2.36 & 2.03 & 1.5 & 6 & $\begin{array}{l}(H= \\
385.54,4 d f)\end{array}$ \\
\hline $\begin{array}{l}\text { What I do is a } \\
\text { threat to the } \\
\text { environment }\end{array}$ & 3.56 & 3.44 & 3.57 & 4.15 & 3.08 & 7 & $\begin{array}{l}(H= \\
64.98,4 \mathrm{df})\end{array}$ \\
\hline $\begin{array}{l}\text { Others don't do } \\
\text { anything }\end{array}$ & 3.38 & 2.32 & 2.57 & 2.24 & 1.67 & 7 & $\begin{array}{l}(H= \\
205.52,4 d f)\end{array}$ \\
\hline Too complicated & 3.55 & 3.8 & 3.14 & 3.21 & 2.83 & 7 & $\begin{array}{l}(\mathrm{H}= \\
86.46,4 \mathrm{df})\end{array}$ \\
\hline \multicolumn{8}{|l|}{ Awareness } \\
\hline $\begin{array}{l}\text { If knew where to } \\
\text { recycle }\end{array}$ & 4.38 & 3.48 & 1.79 & 3.97 & 4.33 & 15 & $\begin{array}{l}(H= \\
229.89,4 d f)\end{array}$ \\
\hline Correct bin & 3.87 & 3.48 & 3.07 & 4.12 & 4.25 & 18 & $\begin{array}{l}(H= \\
86.74,4 d f)\end{array}$ \\
\hline $\begin{array}{l}\text { Need more } \\
\text { information }\end{array}$ & 4.19 & 3.16 & 3.29 & 4.15 & 4.5 & 19 & $\begin{array}{l}(H= \\
154.76,4 d f)\end{array}$ \\
\hline \multicolumn{8}{|l|}{ Values } \\
\hline Social justice & 4.06 & 3.88 & 3.54 & 4.61 & 4.67 & 4 & $\begin{array}{l}(H= \\
61.26,4 \mathrm{df})\end{array}$ \\
\hline $\begin{array}{l}\text { Enjoy luxuries of } \\
\text { life }\end{array}$ & 3.6 & 3.32 & 3.23 & 4.12 & 2.92 & 4 & $\begin{array}{l}(H= \\
52.02,4 d f)\end{array}$ \\
\hline $\begin{array}{l}\text { Humans rule the } \\
\text { world }\end{array}$ & 3.88 & 3.08 & 2.93 & 3.63 & 3.93 & 6 & $\begin{array}{l}(\mathrm{H}= \\
51.41,4 \mathrm{df})\end{array}$ \\
\hline $\begin{array}{l}\text { No limits to } \\
\text { growth }\end{array}$ & 3.81 & 3.08 & 3.57 & 3.61 & 3.42 & 7 & $\begin{array}{l}(H= \\
33.24,4 d f)\end{array}$ \\
\hline
\end{tabular}

